\title{
THE IMPLEMENTATION OF PRINCIPLES OF FOREIGN LANGUAGE TEACHING IN DESIGNING A COURSEBOOK FOR UNIVERSITY MEDICAL STUDENTS
}

\section{Krasnikova S.O., PhD in Philology, Kozka I.K., PhD in Philology, Al-Gazo N.V. (Kharkiv)}

The paper deals with the issues of designing an English language coursebook for university medical students. The coursebook has a dominant role in education as the main means of transferring knowledge. The problems related to design criteria for a manual and its functions have been investigated by both Ukrainian and foreign scientists.

The topicality of the research is specified and predetermined by the need to develop a methodological basis for designing an English language coursebook for university medical students.

The object of the research is a unit structure for an English coursebook for firstyear medical students.

The aim of the work is to present a methodological basis for designing a syllabus of an English course for first-year medical students, to substantiate the implementation of the principles of foreign language teaching in the creation of a coursebook, the main aim of which is the formation of communicative competence with the help of a system of pre-textual, textual and post-textual exercises.

The presentation of the main material. The goal of studying the discipline "The English language" is to form professionally-oriented communicative competence of the students based on studying some English content involving medical terminology and lexis of systems of the human body. The syllabus comprises the following topics: the structure of the human body, the musculoskeletal system, cardiovascular system, lymphatic system and immunity, nervous system, digestive system, respiratory system, urinary system, reproductive system, and the endocrine system. The tasks for each topic involve doing drills, listening to and reading authentic medical texts, watching videos, and doing exercises for self-s tudies.

Conclusion. The authors have concluded that the efficiency of forming the communicative competence of medical students depends on following a certain sequence of (pre-textual, textual, and post-textual) tasks and principles of foreign language teaching in designing units of the coursebook. The researchers have substantiated the necessity of being guided by the didactic and methodological principles in designing a syllabus and coursebook. The authors have analyzed the structure and construction of the units.

Having been guided by the current requirements for a task design defined by the prominent Ukrainian methodologists, the researchers have presented a system of tasks that develop language and speech competences in reading, writing, listening, and speaking for medical students while studying the body systems.

(C) Krasnikova S.O., Kozka I.K., Al-Gazo N.V., 2021 
The perspectives of further research will embrace the creation of an English coursebook for second-year students of medical universities and medical faculties of universities. It will include the description of the diseases of the human body systems studied during the first year.

Key words: body system, coursebook design, principles of foreign language teaching, syllabus, task, type of speech activities.

Краснікова С.О., Козка І.К., Аль-Газо Н.В. Імплементація принципів навчання іноземної мови у розробку підручника для студентів-медиків університетів. $\mathrm{У}$ роботі розглянуті питання розробки підручника 3 англійської мови для студентів-медиків університетів. Підручник відіграє домінантну роль у сфері освіти як основний засіб передачі знань. Проблеми, пов'язані 3 критеріями створення підручника та його функціональності, досліджувались українськими та іноземними вченими.

Актуальність дослідження визначається необхідністю розробити методологічні засади створення підручника з англійської мови для студентів, які вивчають медицину в університеті.

Об 'єкт дослідження - структура розділів підручника для студентівмедиків 1 курсу.

Мета роботи - представити методологічне підгрунтя силабусу курсу англійської мови для студентів-медиків та обгрунтувати імплементацію принципів навчання іноземної мови у створення підручника, основною метою якого $\epsilon$ формування комунікативної компетенції студентів за допомогоюсистеми дотекстових, текстових та післятекстових вправ.

Презентачія матеріалу. Мета вивчення дисципліни «Англійська мова»формування професійно-орієнтованої комунікативної компетенції студентів на основі англомовного контенту, який містить медичну термінологію та лексику систем тіла людини. Підручник складається 3 таких тем: структура тіла людини, скелетно-м'язова система, серцево-судинна система, лімфатична система та імунітет, нервова система, система травлення, дихальна система, сечовидільна система, репродуктивна та ендокринна системи. Завдання до розділів включають виконання вправ, читання та прослуховування автентичних медичних текстів, перегляд відео та вправи для самостійного виконання.

Висновки. Автори дійшли висновку, що ефективність формування комунікативної компетенції студентів-медиків залежить від дотримання певної послідовності виконання вправ та імплементації принципів навчання іноземної мови у розробку розділів підручника. Дослідники обгрунтували необхідність спиратися на дидактичні та методологічні принципи при час розробки силабусу та підручника. Автори проаналізували структуру та побудову розділів. Керуючись сучасними вимогами до створення вправ, визначеними провідними українськими вченими-методистами, дослідники презентували систему вправ, які розвивають мовну та мовленнєву компетенції студентів-медиків 1 курсу у читанні, письмі, аудіюванні та говорінніпід час вивчення систем тіла людини. 
Перспективи подальиих досліджень стосуватимуться створення підручника 3 англійської мови для студентів другого курсу медичних університетів та медичних факультетів університетів. Підручник включатиме опис захворювань систем тіла людини, які вивчались студентами протягом першого курсу.

Ключові слова: вид мовленнєвої діяльності, вправа, принципи навчання іноземних мов, розробка підручника, силабус, системи тіла людини.

Красникова С.А., Козка И.К., Аль-Газо Н.В. Имплементация принципов обучения иностранному языку при разработке учебника для студентов-медиков университетов. В работе рассмотрены вопросы разработки учебника по английскому языку для студентов-медиков университетов. Учебник выполняет доминантную роль в сфере образования как основное средство передачи знаний. Проблемы, связанные с критериями создания учебника и его функциональностью, изучались украинскими и зарубежными учеными.

Актуальность исследования определяется необходимостью разработать методологические основы создания учебника по английскому языку для студентов, которые изучают медицину в университете.

Объект исследования - структура разделов учебника для студентовмедиков 1 курса.

Цель работы - представить методологический базис силлабуса курса английского языка для студентов-медиков и обосновать имплементацию принципов обучения иностранному языку при создании учебника, основной задачей которого является формирование коммуникативной компетенции студентов при помощи системы дотекстовых, текстовых и послетекстовых упражнений.

Презентация материала. Целью изучения дисциплины «Английский язык» является формирование профессионально-ориентированной коммуникативной компетенции студентов на базе английского контента, включающего медицинскую терминологию и лексику систем тела человека. В учебник входят такие темы: структура тела человека, мышечно-скелетная система, сердечно-сосудистая система, лимфатическая система и иммунитет, нервная система, пищеварительная система, дыхательная система, мочевыделительная система, репродуктивная и эндокринная системы. Задания к разделам включают выполнение упражнений, чтение и прослушивание аутентичных медицинских текстов, просмотр видео и упражнения для самостоятельной работы.

Bblводы. Авторы пришли к выводу, что эффективность формирования коммуникативной компетенции студентов-медиков зависит от соблюдения определенной последовательности выполнения упражнений и имплементации принципов обучения иностранному языку при разработке разделов учебника. Исследователи обосновали необходимость руководствоваться дидактическими и методологическими принципами при разработке силлабуса и учебника. Авторы проанализировали структуру и строение разделов, руководствуясь современными требованиями 
купражнениям, определенными ведущими украинскими ученымиметодистами. Исследователи презентовали систему упражнений, которые развивают языковую и речевую компетенции в чтении, письме, аудировании и говорении, для студентов-медиков 1 курса при изучении систем тела человека.

Перспективы дальнейиих исследований будут касаться создания учебника по английскому языку для студентов второго курса медицинских университетов и медицинских факультетов университетов. Учебник будет включать описание заболеваний систем тела человека, которые изучались студентами на протяжении первого курса.

Ключевые слова: вид речевой деятельности, принципы обучения иностранным языкам, разработка учебника, силлабус, системы тела человека, упражнение.

The coursebook has a dominant role in education as the main means of transferring knowledge. It "reflects the methodological conception of the authors, goals, principles, and content of learning, and defines its strategy and tactics" [2: 79]. The issues related to design criteria for a manual and its evaluation, functions, and teacher's roles have been investigated by both Ukrainian and foreign scientists $[1 ; 2 ; 10 ; 14 ; 18]$. Methodologists state the main functions of a coursebook as supplying knowledge with the help of concepts, data, terminology; consolidation and reinforcement of knowledge which is ensured by a system of exercises and tests; knowledge assessment provided by tasks for selfcontrol; knowledge integration consisting of habits and skills acquired beyond one discipline and acquired in studying some disciplines [1: 100]. The function of social and cultural upbringing is also crucial. It concerns habits and skills of social behaviour, people's relations in a society, in social and cultural environments.

The topicality of the research is specif ied and predetermined by the urgent need to develop a methodological bas is for designing an English coursebook for university medical students.

The object of the research is the design of the units for a coursebook of English for medical students.

The aim of the work is to analyze the implementation of the principles of foreign language teaching in the creation of a coursebook for university medical students, to present a scientific rationale for designing a syllabus of a language course for medical students and forming the communicative competence with the help of pre-textual, textual and post-textual exercises. 
The presentation of the main material. The goal of studying the English language at a medical higher educational institution is getting communicative competence as a means for further successful professional activities. The development of this competence will make it possible for the students of medical universities and medical faculties of universities to find solutions to any language issues in the ir future professional careers.

The first-year students of medical and dental specialties have started studying a new educational subject "The English language". This educational discipline deals with medical terminology and lexical and grammatical peculiarities of the English language lexis related to the systems of a human body. Practical lessons include the work on medical terminology based on original medical texts, mastering skills and habits of scanning and skimming, formation of communicative competence based on the syllabus topics.

The goal of the discipline is to form professionally-oriented communicative competence of the students based on the study of the English language content that involves the terminology and vocabulary of the systems of the human body in English.

The course facilitates professional training in the field of medicine and a profound study of medical subjects. The structure of the course includes the number of hours, a list of topics, general and special competences formulated in terms of instruction results, and requirements for the higher education quality assessment (tasks and means of control). The purpose of the discipline is to provide training for highly qualified professionals in the field of medicine. They must be able to find solutions to complex medical issues, do scientific research, obtain new facts and implement their professional competences into medical practice. The course ensures that the students will acquire the knowledge, skills, ways of thinking, and ethical values which are sufficient for future medical specialists to carry out their professional activities.

The course involves 20 hours of classroom work and 50 hours of self-studies for the students of medical specialties. The syllabus includes such topics as follows: the structure of the human body, musculoskeletal system, cardiovascular system, lymphatic system and immunity, nervous system, digestive system, respiratory system, urinary system, reproductive system, and endocrine system. The tasks to each topic envisage doing exercises, listening to original texts on 
medical and dental specialties, and watching videos. Means of control comprise writing tests, questions, finding solutions to current issues of different branches of medical science related to the systems of the human body, searching the Internet for new data, reading international scientific magazines to find solutions to the current issues of medicine which the future medical specialists will face in their future professional activities.

The term "educational procedures of the English language", put forward by prominent scholars in the field of foreign language teaching methodology [Harmer J., Brown H.D., Ur P.] is represented in the practice of teaching fore ign languages to students of medical and dental specialties by methods and techniques of teaching; goals, settings and results of the course; forms of evaluation and control; specific features of the syllabus; and chosen genres of linguistic discourse.

It is advisable to include in the syllabus not only the materials from the recommended sources but also to use articles from scientific magazines, information on the innovations in the domain of current medical issues and new methods of treatment and research, advertisements, etc.

Dealing with the materials in the students' language environment will be more efficient if the rules according to which medical discourses are structured and organized, the principles of their functioning in speech, and the main principles of teaching a foreign language are taken into account while designing a coursebook.

The main principle of teaching a foreign language is a principle of communicativity, and the aim of studying is communicative competence. The content of it (in terminology adopted by Ukrainian methodologists) comprises language competence (language know ledge and corresponding habits), speech competence (skills in listening, speaking, reading, and writing), and sociocultural competence [1: 4243; 2: 73]. From the viewpoint of teaching medical students, we consider the last one as an ability to choose appropriate patterns of linguistic behaviour in a given language environment that resembles a real-life situation.

Communicative competence is aimed at mastering an authentic language. But what determines this process? It is the input that a course-book contains. And this input "should foster meaningful communicative use of the language in appropriate contexts" [10: 78]. Designing a course-book we should anticipate the learners' needs and 
match them with the coursebook's content. Speaking is arguably the most crucial of all four types of speech activities and many if not most of our learners are primarily interested in acquiring an ability to speak. Designing a language course-book has several components and one of them deals with the materials: "For a teacher designing a course, materials development means creating, choosing or adapting and organizing materials and activities so that students can achieve the objectives that will help them reach the goals of the course" [10: 150]. There are certain types of tasks that efficient teachers should rely on. This should include learner-oriented activities, gap filling, and problem-solving. According to K. Bailey, activities "involving information gaps can be used at all levels of instruction to create communicative needs and motivate interaction" [3: 129]. Sometimes the lessons are overwhelmed with rote, mechanical drills that center mainly on a form. We do not reject the importance of drills, especially at the beginner level, but what is important is a meaningful practice: "...it appears that contextualized, appropriate, meaningful communication in the second language seems to be the best possible practice the second language learner could engage in" [10: 77].

The next principle of visualization concerns the usage of visual aids [1: 48; 2: 82]. A good teacher can hardly imagine his classes without them. Pictures are not just an aspect of the method, but through their representation of places, objects, and people they are an essential part of the language experiences we must help our students to cope with. That's why we have included the medical educational pictures and pictures for a discussion into the units of a course-book. Choosing visual aids the teacher should take into consideration the purpose of the lesson in its relation to the syllabus, the objectiveness of the lesson, and the specific characteristics of the group of the lesson, communication problems (some students can feel shy, anxious, or feel difficulties in relationship with their group mates). Most experienced teachers use visual aids to teach the four types of speech activities (speaking, listening, reading, and writing). Visual aids are of great help in the organization of students for communication in a language classroom, making the teaching process more efficient and the learning process more challenging. Also, the visual aids inspire the students to speak not only about medicine but also about social and psychological problems connected with it. 
Watching video is one of the most effective techniques in learning a language, and students always wait for and work with pleasure on video materials, and the lessons are very interesting for them. Some teachers consider that the possibilities of video at the English lessons are unbelievable and innumerable.

There are some advantages of applying the principle of graded tasks [1: 11; 2: 72]. All students are challenged at an appropriate level of difficulty and can get involved in doing the task. No one should be left behind or have nothing to do. All students can succeed in completing the task given to them, and this is motivating for them. The teacher can design various tasks for lots of different activity types (e.g. listening, reading, vocabulary practice). This approach also promotes student cooperation and tolerance. But students should not feel labelled as weak, medium, or strong and therefore embarrassed. The weaker students in particular should not feel demotivated. And practical teachers do know that much more preparation is needed for those who apply this approach in their professional activities. If strong students are given more challenging work to do, it is less likely that they will finish quickly. The teacher can get the stronger students involved by getting them to explain: making sure that all students are involved is part of good classroom management. When the teacher spends time teaching a group of weaker students, the stronger students can be doing another task. Brilliant students should not be regarded as a threat. If you have reference books available in the class (which is often a good idea), then get the students to look the answer up. The teacher should remember that recognition of effort and progress is as important as achievement; evaluation and assessment are crucial stages of a lesson. Of course, we should refrain from labelling some students as "slow" or "dumb" and others as "brilliant" or "bright" but the reality is while some students have done three exercises in seven minutes the others have coped only with one. That's why the teacher should always have "something up his/her sleeve", and each unit comprises not one but several exercises with the task to complete a sentence, match a term and a definition, choose a correct option, etc.

The principle of integrated teaching of four types of speech activities helps organize the process of teaching most effectively [2:74]. Lexical and grammatical skills are improved in the process of speaking, listening, reading, and writing. Thus, coherence in teaching 
language habits and skills promotes complex development of speech skills and habits.

The principle of dominating role of exercises [2: 73] stresses the importance of a variety of tasks to develop habits and skills of speech activities in a foreign language.

S. Nikolayeva, O. Bigych, S. Haponova, L. Panova, O. Petraschuk, N. Sklyarenko, and other Ukrainian methodologists distinguish three types of exercises according to the principle of communicativity: communicative (or speech) tasks, relatively-communicative (or relatively-speech) tasks, and non-communicative (or language) tasks [1:66]. In communicative activities a learner realizes the speech act in a foreign language he/she is acquiring. The main characteristic feature of relatively-speech tasks is the presence of speech instruction and reallife situations. In non-communicative tasks, the focus is only on the form [1: 67].

Also, the principles of active participation, the dominant role of the exercises, accessibility of knowledge, individual approach to students have been taken into consideration. The creative teacher is constantly searching for current techniques and methods which would promote the goals of studying. We study medical terminology at the English lessons. So, the issue of potential lexis is crucial. It is known that there are some sources of its formation. They are not an object of our research study. During classes, we deal with one of them: stating the term meaning by analysis of its word parts (roots, prefixes, suffixes). The tasks connected with analyzing the combining forms are also included in the units of the coursebook.

We use mostly scanning (reading with full understanding) and reading for detail (searching for necessary information) in designing texts for reading [2: 174-175].

In designing a task the teacher should be guided by such questions: How many steps were involved in the task? Was any monitoring involved? Was the level of the task commensurate with the level of the learners? Were the learners able to perform the task? Was collaboration/interaction involved? Which of the tasks that students have done worked well and which didn't? Can you isolate the responsible factors?

We propose to apply the system of non-communicative, relativelycommunicative and communicative exercises [1: 67] for medical students of the intermediate level in dealing with the topics 
"Cardiovascular system", "Respiratory system" and "Digestive system" when the tasks are presented as pre-textual, textual and post-textual. This classification corresponds to the classification in which the exercises are grouped at such stages of the lesson: "Presentation", "Practice", and "Production" [14: 25].

The group of pre-textual tasks includes the following exercises

Task 1. Check if you understand the meaning of the following terms: vessel, nutrient, myocardium, ventricle, septum, mitral valve, diastole, systole, epicardium, chamber, tricuspid valve, tachypnea, bradypnea, oropharynx, epiglottis, mediastinum, pylorus, gallbladder, pancreas, jejunum, immunoassay, salivary gland, ulcer, ileum, etc.

Task 2. Give the definitions of the terms:

Vessel, epicardium, ventricle, superior vena cava, septum, emphysema, apnea, sputum, intestine, mucosa, ascites, etc.

We have chosen some terms for this task to stimulate the students' knowledge, to develop the habit of working with medical dictionaries, and to facilitate their memory skills.

Task 3. Study the pictures "Structures of the Heart", "Structures of the Respiratory System", "Structures of the Digestive System".

Task 4. Study the word parts. In this exercise we also present the meaning of these word parts:

endo- (within, inner), -ectasis (dilation), peri- (around), ather/o (fatty), -itis (inflammation), dors/o (back), ped/o (foot), orlo (mouth), -osmia (smell), steth/o (chest), -lith (stone), bucclo (cheek), -emesis (vomiting), gingiv/o (gums), gloss/o (tongue), laparlo (abdomen), -pepsia (digestion), etc.

Task 5. Divide the terms into the word parts (prefix, root, and suffix). Give the meaning of each word part and the definition of the word itself.

The students are asked to divide the terms into the combining parts (angioscope, phlebectasia, atrioventricular, bronchiectasis, buccolabial, cholecystic, hematemesis, etc. For example: bucc/o = cheek, - labi/o =lip, $-a l=$ pertaining to. The general meaning of the term $=$ "pertaining to the cheeks and lips". Cholecyst/o = gallbladder, $-i c=$ pertaining to. The general meaning of the term $=$ "pertaining to the gallbladder". Hemat/o = blood, -emesis = vomiting. The general meaning of the term = "vomiting blood".

Task 6. Complete the term by writing the missing word or word part. 
1. Hemi_ectomy $=$ removal of half of the stomach. 2._itis = inflammation of the appendix. 3. Pyloric _- = narrowed condition of the pylorus. 4. Chol___ gram = X-ray image of bile ducts (vessels). 5. __bilirubin__ = excessive level of bilirubin in the blood.

6. Gastric ___ = partial removal and repair of the stomach.

Task 7 . Then the students read the text, using techniques of scanning and reading to search for necessary information.

The text in the unit "Cardiovascular system" deals with the main structural parts of the circulatory system and their functions, transportation of deoxygenated blood to the lungs to get oxygen, transportation of oxygenated blood away from the heart to the tissues and cells, the four chambers of the heart and its three layers, and different heart conditions. The text of the unit "Respiratory system" analyzes functions of the structures of the upper and lower respiratory tracts, the processes of inhalation and exhalation. It seemed advisable to include into the unit which concerns the diseases of the digestive system the text for reading "Structures of the digestive system" and the text which deals with the invasive and non-invasive diagnoses of Helicobacter pylori infection. A future doctor needs to know the methods of investigation of different diseases. The test of a gastric mucosal biopsy obtained through a gastroscope, which is considered to be the gold standard for Helicobacter pylori detecting, has been discussed in the text.

The group of textual tasks includes: Task 8. Find in the text the opposites to the words: symptomatic, invasive, inaccurate. Task 9. Find the pairs of synonyms among the given words: to detect, specimen, to consider, rapid, to put, to perform, quick, to insert, to make, sample, to believe, to find. Task 10. What do these abbreviations stand for? 1. CABG. 2. HDL 3. SOB. 4. CAD. 5. CCU. 6. CHF. Task 11. Write the plural forms of the nouns: bronchus, cilium, rhonchus, pleura, alveolus.

The group of post-textual tasks includes the tasks for sentence completion, matching, and multiple choice. Task 12. Fill in the blanks with the words: blocked, procedure, insertion, stent. Surgical procedures for treating blockages in blood vessels include the following: Percutaneous transluminal coronary angioplasty (PTCA) involves the 1__ of a balloon-tipped catheter to open a blocked coronary artery. Arterial 2__ includes the implantation of a stent, which is a mesh tube that is implanted into an artery to provide support. 
Coronary artery bypass graft (CABG) is a surgical 3__in which a damaged section of a coronary artery is replaced or bypassed with a graft vessel. Endarterectomy is the removal of the inner lining of a 4__artery.

Task 13. Match a term and a definition. The terms are: tachypnea, dyspnea, bradypnea, apnea. The definitions are: "rapid breathing rate", "abnormally slow breathing rate", "cessation of breathing", "difficulty in breathing while lying flat".

We have included in the units the tasks to develop skills of monological and dialogical speech in the settings of situations that simulate real-life conditions; there are project tasks involving the skills of working with reference literature and doing crosswords. It is very important to organize the work in situations that simulate real-life interaction for different dia logical and monological activities in which various social roles and partners are involved (a nurse, a doctor, surgeon-trainees, etc). The individual approach to students works when they suggest their personal decisions to finding the solution to a medical problem. The discussion and presenting points of view make it possible to develop the basis for the ir future behaviour in a professional medical environment.

Conclusions. To start with, it was an urgent need to develop methodological basics for designing an English coursebook for university medical students.

Firstly, the authors have concluded that the efficiency of formation of the communicative competence of medical students depends on keeping a definite task sequence and principles of a foreign language teaching in designing units of the coursebook. We have substantiated the application of didactic and methodological principles in designing a coursebook. Furthermore, we have analyzed the structure of the units and have shown how they have been constructed. We have presented scientific grounding for designing a syllabus of a language course for medical students and forming communicative competence with the help of pre-textual, textual, and post-textual exercises. According to the syllabus, the goal of the discipline is to form professionally-oriented communicative competence of the students based on the study of the English language content involving medical terminology and lexis of systems of a human body. Such themes are included in the syllabus: structure of a human body, musculoskeletal system, cardiovascular system, lymphatic system and immunity, nervous system, digestive 
system, respiratory system, urinary system, reproductive system, and endocrine system.

Moreover, the researchers have presented a system of tasks that develop speech and language competences in reading, writing, listening, and speaking for medical students in tackling the systems of a human body. It is very crucial to include in the coursebook the tasks on listening to authentic medical texts, watching videos, and exercises for self-studies.

The authors have used the current demands for a task design, having been stated by the Ukrainian methodologists who divide the tasks according to the principle of communicativity into non-communicative (language), relatively communicative, and communicative. Also, the principles of integrated teaching of all kinds of speech activities, visual aids, active participation, the dominant role of the exercises, accessibility of knowledge, individual approach to students have been taken into consideration.

Finally, the methods and techniques, the coursebook for medical students is based on, represent the main guidelines used in traditional and more recent approaches.

The authors have included warm-up and eliciting activities into the coursebook for medical students. They consider that information gap exercises should be in the repertoire of any good teacher. The current methodology of foreign language teaching has made a shift of emphasis to student-centred learning, and the authors demonstrated the practical implementation of this principle in designing a medical coursebook. The researchers have tried to make teachers more aware of the roles as helpers and facilitators and not principals and managers in the process of teaching.

Summing up, we should state that future doctors should not only master the course "The English language" but have to be aware that English is a means of acquiring new knowledge, expanding professional interaction possibilities that form the sense of unity with the world medical community and the personality of the modern-day doctor.

The perspectives of the further research will deal with the creation of an English coursebook for second-year students of the medical universities and medical faculties of the universities. It will include the description of the diseases of the human body systems studied during the first year. 


\section{LITERATURE}

1. Ніколаєва С.Ю., Бігич О.Б., Гапонова С.В., Скляренко Н.К. та ін. Методика навчання іноземних мов у середніх навчальних закладах: підручник. К.: Ленвіт, 1999. 320 с.

2. Панова Л.С., Андрійко І.Ф., Тезікова С.В. та ін. Методика навчання іноземних мов у загальноосвітніх навчальних закладах: підручник. К.: ВЦ «Академія» 2010. 328 с. (Серія «Альма-матер»).

3. Bailey K.M. Practical Eng lish Language Teaching: Speaking. Mc Graw Hill, 2005. 199 p.

4. Bhatia V.K. Analyzing Genre: language use in professional settings. London: Longman, 1993. 246 p.

5. Bhatia V.K. Generic Patterns in Fundraising Discourse. New Directions for Philanthropic Fundraising. 1998. № 2. P. 5-110.

6. Bhatia V.K. Genre Analysis and World Englishes. World Englishes. Blackwell Publishers, 1997. № 11. Volume 16. Issue 3. P. 313-319.

7. Bhatia V.K. Genre Analysis Today. Revue belge de Philologie et d'Histoire. Annee. 1997. № 75-3. P. 629-652.

8. Bhatia V.K. Genre - Mixing in Academic Introductions. English for Specific Purposes. 1997. 1/1.Volume 16, Issue 3. P. 181-195.

9. Bhatia V.K. Towards Critical Genre Analysis. Advances in Discourse Studies. Psychology Press. 2008. 3/10. P. 150-186.

10. Brown H.D. Principles of Language Learning and Teaching. $5^{\text {th }}$ ed. Pearson Education. 2007. 410 p.

11. Dudley-Evans T., Saint John M.J. Developments in English for Specific Purposes: a multi-disciplinary approach. Cambridge: Cambridge University Press, 1998. 301 p.

12. Glendinning E.H. English in Medicine. Cambridge: Cambridge University Press, 2015. 153 p.

13. Grice T. Oxford English for Careers. Nursing 2. Student's Book. Oxford: Oxford University Press, 2018. 135 p.

14. Harmer J. The Practice of English Language Teaching. Fourth edition. Harlow: Pears on Education Limited, 2007. 448 p.

15. Knapp K., Seid lhofer B. Handbook of Fore ign Language Communication and Learning. Vienna: De Gruyter Mouton, 2019. 730 p.

16. Mamone L, Jones J, Shiguang L. Multiple Myeloma: The Case of the Disappearing Band. Laboratory Medicine. 2018. Volume 49, Issue 1, February 2018. P. 87-91. URL: https://academic.oup.com/ labmed/pages/selected_case_studies_2018 (accessed 20.12.2020).

17. Nagy W.E. Teaching Vocabulary to Improve Reading Comprehension. Newark: International Reading Association, 2003. 43 p. 
18. New Methodological Approaches to Foreign Language Teaching / ed. L. Torres-Zunica and T.H. Schmidt. Cambridge: Cambridge Scholars Publishing, 2017. $178 \mathrm{p}$.

19. Swales J.M. Aspects of Article Introductions. Aston ESP Research Report № 1. Language Studies Unit. Birmingham: University of Astonin, 1981. $95 \mathrm{p}$.

20. Swales J.M. Genre Analysis: English in academic and research settings. Cambridge: Cambridge University Press, 1990. 260 p.

21. Swales J.M., Feak C.B. Academic Writing for Graduate Students: Essential tasks and skills. Ann Arbor: University of Michigan, 2004. 282 p.

22. Wahed A., Dasgupta A. Hematology and Coagulation. A Comprehensive Review for Board Preparation, Certification and Clinical Practice. Oxford: Elsevier Inc, 2015. 305 p.

\section{REFERENCES}

1. Nikolayeva, C.J., Bigich, O.B., Gaponova, S.V. et al. (1999). Metodyka navchannya inozemnykh mov u serednikh navchalnykh zakladakh [Methods of teaching foreign languages in secondary schools]. Kyiv: Lenvit [in Ukrainian].

2. Panova, L.S., Andriyko, I.F., Tezikova S.V. et al. (2010). Metodyka navchannya inozemnykh mov u zahalnoosvitnikh navchalnykh zakladakh [Methods of teaching foreign languages in comprehensive schools]. Kyiv: VC "Academiya" [in Ukrainian].

3. Bailey, K.M. (2005). Practical Eng lish Language Teaching: Speaking. Mc Graw - Hill [in English].

4. Bhatia, V.K. (1993). Analyzing Genre: language use in professional settings. London: Longman [in English].

5. Bhatia, V.K. (1998). Generic Patterns in Fundraising Discourse. New Directions for Philanthropic Fundraising, 2, pp. 5-110 [in English].

6. Bhatia, V.K. (1997). Genre Analysis and World Englishes. World Englishes. Blackwell Publishers. 11, Volume 16, Issue 3, pp. 313-319 [in English].

7. Bhatia, V.K. (1997). Genre Analysis Today. Revue belge de Philologie et d'Histoire. 75-3, pp. 629-652 [in English].

8. Bhatia, V.K. (1997). Genre - Mixing in Academic Introductions. English for Specific Purposes. 1/1.Volume 16, Issue 3, pp. 181-195 [in English].

9. Bhatia, V.K. (2008). Towards Critical Genre Analysis. Advances in Discourse Studies. Psychology Press. 3/10, pp. 150-186 [in English].

10. Brown, H.D. (2007). Principles of Language Learning and Teaching. $5^{\text {th }}$ ed. Pearson Education [in English]. 
11. Duddley-Evans, T. and Saint John, M.J. (1998). Developments in English for Specific Purposes: a multi-disciplinary approach. Cambridge: Cambridge University Press [in English].

12. Glendinning, E.H. (2015). English in Medicine. Cambridge: Cambridge University Press [in English].

13. Grice, T. (2018). Oxford English for Careers. Nursing 2. Student's Book. Oxford: Oxford University Press [in English].

14. Harmer, J. (2007). The Practice of English Language Teaching. Fourth edition. Harlow: Pearson Education Limited [in English].

15. Knapp, K. and Seidlhofer, B. (2019). Handbook of Foreign Language Communication and Learning. Vienna: De Gruyter Mouton [in English].

16. Mamone, L., Jones, J. and Shiguang, L. (2018). Multiple Myeloma: The Case of the Disappearing Band. Laboratory Medicine, Volume 49, Issue 1, February 2018, pp.87-91. Available at: https://academic.oup.com/ labmed/pages/selected_case_studies_2018 [Accessed 20.12.2020] [in English].

17. Nagy, W.E. (2003). Teaching Vocabulary to Improve Reading Comprehension. Newark: International Reading Association [in English].

18. Torres-Zunica, L. and Schmidt, T.H. (Eds.). (2017). New Methodological Approaches to Foreign Language Teaching. Cambridge: Cambridge Scholars Publishing [in English].

19. Swales, J. (1981). Aspects of Article Introductions. Aston ESP Research Report № 1. Language Studies Unit. Birmingham: University of Astonin [in English].

20. Swales, J.M. (1990). Genre Analysis: English in academic and research settings. Cambridge: Cambridge University Press [in English].

21. Swales, J.M. and Feak, C.B. (2004). Academic Writing for Graduate Students: Essential tasks and skills. Ann Arbor: University of Michigan [in English].

22. Wahed, A. and Dasgupta, A. (2015). Hematology and Coagulation. A Comprehensive Review for Board Preparation, Certification and Clinical Practice. Oxford: Elsevier Inc [in English].

Красні кова Світлана Олександрівна, канд. філол. наук, професор, завідувач кафедри мовної підго товки іноземних громадян Харківського національного медичного університету (61022, Харків, пр. Науки, 4); еmail: s_krasnikova@ukr.net; orcid: http://orcid.org/0000-0002-7155-4436.

Красникова Светлана Александ ровна, канд. филол. наук, профессор, заведующий кафедрой языковой подготовки иностранных граждан Харьковского национального медицинского университета (61022, Харьков, пр. Науки, 4); e-mail: s_krasnikova@ukr.net; orcid: http://orcid.org/0000-0002-7155-4436. 
Svitlana Krasnikova, $\mathrm{PhD}$ in Philology, Professor, Head of the Language Training Department for Foreign Citizens, Kharkiv National Medical University (61022, Kharkiv, 4 Nauky Avenue); e-mail: s_krasnikova@ukr.net; orcid: http://orcid.org/0000-0002-7155-4436.

Козка Ірина Кирилівна, канд. філол. наук, доцент кафедри мовної підго товки іноземних громадян Харківського національного медичного університету (61022, Харків, проспект Науки, 4); e-mail: iryna.kozka@gmail.com; orcid: http://orcid.org/0000-0002-2414-0249.

Козка Ирина Кирилловна, канд. филол. наук, доцент кафедры язы ковой подго товки иностранных граждан Харьковского национального медицинского университета (61022, Харьков, проспект Науки, 4); e-mail: iryna.kozka@gmail.com; orcid: http://orcid.org/0000-0002-2414-0249.

Iryna Kozka, PhD in Philology, Associate Professor, Language Training Department for Foreign Citizens, Kharkiv National Medical University (61022, Kharkiv, 4 Nauky Avenue); e-mail: iryna.kozka@gmail.com; orcid: http://orcid.org/0000-0002-2414-0249.

Аль-Газо Наталія Вітальєвна, старший викладач кафедри мовної підго товки іноземних громадян Харківського національного медичного університету (61022, Харків, проспект Науки, 4); e-mail: al.gazo.nata@gmail.com; orcid: http://orcid.org/0000-0002-2494-0086.

Аль-Газо Наталья Витальевна, старший преподаватель кафедры языковой по дго товки иностранных граждан Харьковского национального медицинского университета (61022, Харьков, проспект Науки, 4); e-mail: al.gazo.nata@gmail.com; orcid: orcid: http://orcid.org/0000-0002-2494-0086.

Nataliya Al-Gazo, Assistant Professor, Language Training Department for Foreign Citizens, Kharkiv National Medical University (61022, Kharkiv, 4 Nauky Avenue); e-mail: al.gazo.nata@gmail.com; orcid: http://orcid.org/0000-0002-2494-0086. 